\title{
The movement to SpecFinP in Finnish
}

\author{
Saara Huhmarniemi \\ University of Helsinki \\ saara.huhmarniemi@helsinki.fi
}

\begin{abstract}
This paper investigates the hypothesis that movement to SpecFinP in Finnish is an instance of discourse neutral EPP movement that obeys a locality condition. It is proposed that the subject argument in the specifier of $v P$ is the closest potential goal for the EPP and therefore the "default" element to move to SpecFinP. The other elements, such as the object argument, have to first reach the edge of $v P$ in order to be available for EPP movement to higher positions. The movement of the object to the edge of $v \mathrm{P}$ is argued to be discourse-driven scrambling.
\end{abstract}

Keywords: Finnish; syntax; movement; topicality; EPP

\section{Introduction}

Finnish is sometimes considered to be a topic-prominent language because the canonical subject position is able to host topical elements, as illustrated in examples $(1 \mathrm{a}-\mathrm{b})$. Example (a) shows the canonical SVO word order, while in example (b), the object argument occurs preverbally, and the subject is postverbal. ${ }^{1}$

(1) a. Pekka soitti tämän laulun. (SVO)

Pekka.NOM play.PST.3SG this.ACC song.ACC

'Pekka played this song.'

${ }^{1}$ Glossing abbreviations are used as follows: 1 first person, 2 second person, 3 third person, ACC accusative case, GEN genitive case, INF infinitive (TA-infinitive), NOM nominative case, PAR partitive case, PL plural number, PRES present tense, PST past tense, SG singular number. Finnish has several direct object case forms. The direct object may occur in the partitive case, which indicates unbounded quantity or imperfective aspectual reading of the event (Heinämäki 1984). Perfective contexts manifest three accusative case forms; pronouns and plural NPs appear in the $t$-form. Singular NPs occur either in the $n$-form or in the nominative form depending on the context. In this paper, the abbreviation ACC is used for all of these forms. The semantic cases are glossed with English prepositions. 

b. Tämän laulun soitti Pekka. (OVS) this.ACC song.ACC play.PST.3sG Pekka.NOM 'This song was played by Pekka.'

In generative syntactic theories on Finnish word order, the sentences $(1 \mathrm{a}-\mathrm{b})$ are typically assumed to involve movement of the subject or the object argument to the specifier of a functional projection at the left periphery of the finite clause. In this paper, this projection is referred to as the Fin(iteness) projection (FinP) and the position that is occupied by the moved phrase is the specifier of the FinP (SpecFinP). Other elements, such as adverbials and expletives can also occur in this position.

In the previous research, various discourse notions have been presented as responsible for this movement. Among them are topicality (Koskinen 1998), presupposed information (Holmberg \& Nikanne 2002), and discourse anaphoricity (López 2009; Jokilehto 2017). Yet, the exact triggers of movement to SpecFinP have remained an open question and, in addition, there exists a controversy between the subject and other elements. For example, the non-referential object mitä tahansa 'anything, whatever' cannot obtain the SpecFinP in a given context in example (2a). However, a non-referential subject argument is able to occupy the SpecFinP in the same context (2b) (see also Hakulinen et al. 2004, §1372).

(2) Context:

Tämä laulaja on kuuluisa.

this.NOM singer.NOM is famous.NOM

'This singer is famous.'
a. *Mitä tahansa laulaa hän.
what.PAR ever sings.PRES.3SG s/he.NOM
Intended: 'She sings anything.'
b. Kuka tahansa arvostaa häntä.
who.NOM ever appreciate.PRES.3SG s/he.PAR
'Everyone appreciates her.'

It thus seems that the discourse conditions for the movement of the subject and the object are not uniform. The special status of the subject argument has already been acknowledged by Vilkuna (1989). According to Hakulinen et al. (2004, §1372), the subject is the default element in the preverbal position (referred to as teemapaikka, 'theme position'). Along the same lines, Manninen $(2003,185)$ assumes that the discourse properties of an element are not the only trigger for movement to SpecFinP. Instead, agent arguments of transitive and unergative clauses "yield neutral interpretations 
when raised to SpecFinP". Similar observations have also been made by Kaiser (2006); Holmberg (2010); Brattico (2016), among others.The aim of this paper is to investigate the triggers for movement to SpecFinP and to show that movement of the subject cannot be explained by relying only on discourse features.

The finite clauses examined in this paper are assumed to obey the Extended Projection Principle (EPP), which states that SpecFinP has to be filled. For example, the verb-initial sentence (3) is ungrammatical unless the verb is contrasted (see e.g., Välimaa-Blum 1988, 78-79; Vainikka 1989; Vilkuna 1995, 250, and Kaiser 2006). The EPP is here implemented with an EPP-feature of Fin head that triggers movement.

(3) Lähtee Pekka kotiin. (without emphasis on the verb)

leave.PRES.3SG Pekka.NOM home.to

This paper presents a syntactic analysis of EPP that accounts for the exceptional behaviour of the subject argument without compromising the discourse-driven movement of other elements. According to the proposed analysis, movement of the subject is discourse-neutral EPP movement, while movement of the object argument involves two steps: discourseinduced scrambling to the edge of $v \mathrm{P}$ and consecutive EPP movement to SpecFinP. The two processes are illustrated in figures (4a) and (b). ${ }^{2}$

(4) a. Movement of the subject, cf. (1a) b. Movement of the object argument, cf. (1b)
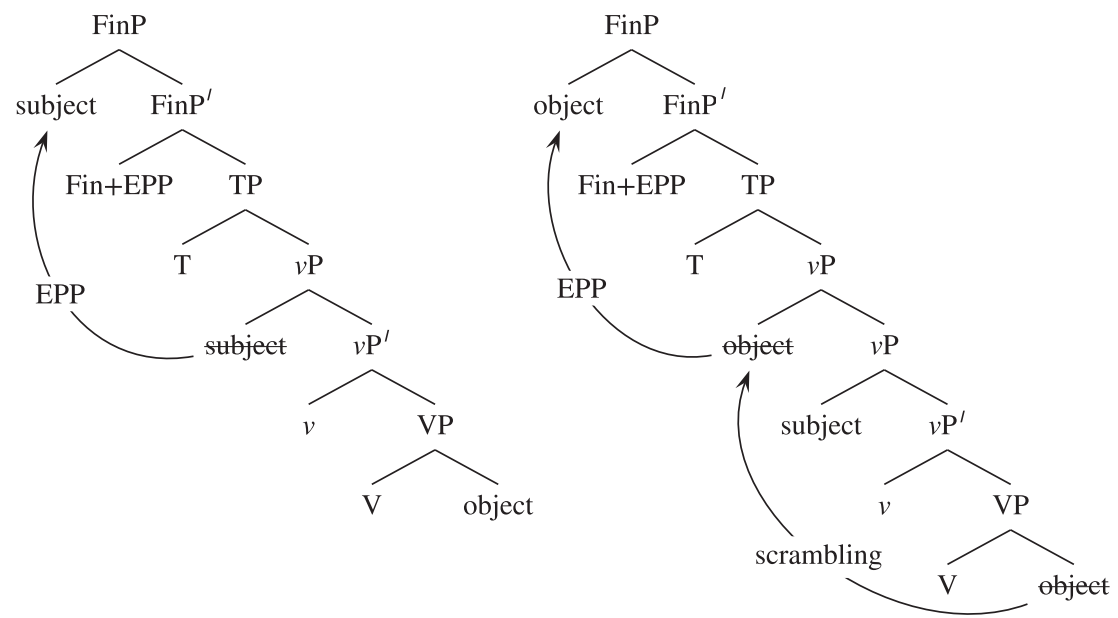

${ }^{2}$ Both of these processes can involve an intermediate landing site at the edge of TP. 
The syntactic analysis is performed in the framework of the minimalist program (Chomsky 1995; 2000; 2001). First, the thematic argument structure is formed within a verb phrase, $v \mathrm{P}$. The direct object is base-generated as the complement of the verb and the subject argument as the specifier of $v \mathrm{P}$. The $\mathrm{T}$ (ense) head is merged with the $v \mathrm{P}$, and the Fin(iteness) head with the TP. In addition, it is assumed that the Fin-head enters into an Agree relation with the subject argument in Spec $v \mathrm{P}$ and assigns the nominative case to the subject. The agreement features of the subject are valued to the Fin head (Holmberg \& Nikanne 2002). ${ }^{3}$ In the canonical word order in Finnish, the subject moves to the specifier of FinP. ${ }^{4}$ In addition, the finite verb moves to the Fin ${ }^{0}$.

It is thus argued that EPP movement to SpecFinP is not sensitive to the discourse properties of the moved element. Nevertheless, the EPP follows the locality condition Attract Closest (Chomsky 1995), which states that if the structure contains more than one potential target for movement, the closest one is selected. The subject argument that occupies Spec $v \mathrm{P}$ is therefore the closest potential goal for the EPP. However, in order for the object argument to be selected for the EPP, it has to first move from the complement of $\mathrm{V}$ to the edge of $v \mathrm{P}$ (or a higher position), where it is reachable by the EPP. This movement is assumed to be scrambling, triggered among others by discourse anaphoricity (e.g., Boef \& Dal Pozzo 2012; Jokilehto 2017).

The present proposal is reminiscent to the proposal by Hiraiwa (2001) for Scandinavian languages. According to Hiraiwa, the EPP selects the closest potential goal for movement, and the parametric differences between Scandinavian languages correlate with the properties of object shift in these languages.

The paper is organised as follows: Section 2 provides an overview of the left periphery of Finnish finite clauses. Section 3 discusses previous

${ }^{3}$ Holmberg \& Nikanne (2002) have argued in detail that the nominative Case in Finnish is not checked in the specifier of FinP, but in a non-local relation between the nominative subject and the Fin head. The main evidence for non-local case assignment is that SpecFinP can be occupied by other than nominative elements. For example, the partitive expletive sitä may occur at the SpecFinP in the multiple subject construction (i) and in partitive constructions, passives, and generic subject constructions.

(i) sitä ovat nämä lapset jo oppineet uimaan

EXP have these children already learnt to-swim

'these children have already learnt to swim'

(Holmberg \& Nikanne 2002)

${ }^{4}$ Example (4a) is a simplified presentation of Finnish syntactic structure; typically finite clause contains also other functional projections, such as NegP or AspP. 
accounts for movement to SpecFinP. Scrambling of the object argument is considered in section 4 . Section 5 introduces the proposed model, and section 6 presents the conclusions.

\section{Discourse properties of the left periphery of the Finnish finite clause}

The information structure of an utterance relates it to its linguistic and non-linguistic contexts. A center of attention has often been in the analysis of functional projections located at the left periphery of the finite clause (e.g., Brody 1995; Rizzi 1997; É. Kiss 1998; Molnár \& Järventausta 2003; Vallduví \& Vilkuna 1998; Frey 2004). The elements that express the discourse notions are assumed to possess a feature that triggers movement to a relevant projection. The aim of this paper is to investigate the triggers that have been associated with the Finnish SpecFinP. The following section 2.1 introduces the left periphery of the Finnish finite clause, section 2.2 provides a background for the relevant discourse notions, and section 2.3 contains a brief note about information structure and prosody.

\subsection{The left periphery of the Finnish finite clause}

According to Vilkuna (1989), the Finnish finite clause contains two discourse-related left peripheral fields as presented in (5). The first position hosts wh-phrases and contrasted elements, among others, and the second position hosts subjects and topical elements. ${ }^{5}$

(5) [ Contrast/wh-phrase [ Topic/subject [ verb [ ... ]]]]

K-field T-field

This basic division into two fields has been a starting point for most existing analyses of the left periphery of the Finnish finite clause. In syntactic theories, the two fields are associated with functional projections (Vainikka 1989; Koskinen 1998; Vallduví \& Vilkuna 1998; Holmberg \& Nikanne 2002; Manninen 2003; Kaiser 2006; Huhmarniemi 2012; Brattico et al. 2014; Jokilehto 2017). The two structural positions corresponding K-field and T-field are here referred to as SpecOpP and SpecFinP.

${ }^{5}$ The characterisation of Contrast and Topic was already presented by Karttunen \& Kay (1985). Vilkuna (1989) developed this idea into the theory of the Finnish left periphery. 


\subsection{Information structure}

This section introduces the central concepts of information structure considered in this paper, topicality, new information, discourse anaphoricity, and contrast.

Topics are often defined in terms of aboutness. Aboutness topics are entities that the remainder of the sentence provides information about (Reinhart 1981; Molnár 1998; Krifka 2007). The remainder of the sentence constitutes the comment. In addition, Reinhart (1981) differentiates between sentence topies from discourse topics, which designate the more general question under discussion in a conversation or, for example, a text paragraph (van Dijk 1977). While the sentence topic is expressed in the sentence, the discourse topic may be implicit. This paper considers only sentence topics.

The comment can be further divided into the part that is background and the part that constitutes the new information (Neeleman et al. 2009). In Finnish, the constituent that is new information is typically located at the end of the sentence (Vilkuna 1995; Holmberg \& Nikanne 2002).

Frascarelli \& Hinterhölzl (2007) suggest on the basis of data from German and Italian that topics fall into three categories: aboutness shift topics, contrastive topics, and familiar topics, which all appear in different syntactic positions in these languages. While there can be only one aboutness shift topic and one contrastive topic in a sentence in these languages, there can be more than one familiar topic.

Let us consider briefly these notions of topicality in Finnish. First, aboutness shift topics are not syntactically represented in Finnish, and they are thus not restricted to a dedicated syntactic position (Jokilehto 2017, 135). In particular, Finnish does not have a left-peripheral topic position outside the CP familiar from other languages, such as English (Chomsky 1977). Second, Finnish contrastive topics are realised either in a projection above FinP or elsewhere in the sentence (Vilkuna 1995; Molnár 2006). This notion of topic is therefore not directly relevant for the investigation of SpecFinP.

Of the three notions of topicality presented by Frascarelli \& Hinterhölzl (2007), the notion of familiar topic seems to be the most promising concept for explaining the discourse properties of SpecFinP (see also Brattico et al. 2014). The familiar topic is a discourse linked constituent that often appears as a pronoun (see also Pesetsky 1987). According to Bianchi \& Frascarelli (2010), only familiar topics may appear in embedded clauses. In Finnish, the SpecFinP has similar properties in both root 
and embedded clauses. Familiarity as a trigger for movement to SpecFinP is discussed in section 3.2.

The final notion of topic discussed here is the frame topic, which provides the "spatial, temporal, or individual framework within which the main predication holds" (Chafe 1976, 50). The frame topics can occur at the beginning of the sentence, as the phrase tänä vuonna 'this year' in example (6). In this example, the frame topic is placed above SpecFinP. Although this position is in Finnish typically associated with contrast, certain adverbials may occur there without the contrastive interpretation (Vilkuna 1989).

(6) Tänä vuonna minä en saanut yhtään lomaa.

this year I.NOM not.1SG get.PAST.SG any vacation.PAR

'This year I didn't get any vacation.'

Jokilehto (2017) proposes that the aboutness shift topics, familiar topics, contrastive topics and frame topics are all processing effort minimisers (PEM), as presented in Relevance Theory (Sperber \& Wilson 1986). According to Jokilehto PEMs are marked with the feature $m$, which distinguishes the PEMs from the comment. The $m$-feature can be realised through movement, morphologically, or phonologically. Jokilehto (2017) discusses Finnish and Hungarian and proposes that $m$-marking triggers movement of the constituent out of the comment domain in both of these languages.

A central property of $m$-marked constituents in Jokilehto (2017) is discourse anaphoricity, and this concept is also adopted here. We will assume the following definition for discourse anaphors: an element is discourse anaphoric if it refers to an entity that has been previously mentioned in the discourse or is part of the common ground (7) (de de Hoop 2003). Elements that are not discourse anaphoric are discourse-new, which means that the referent is introduced to the discourse first time.

(7) Discourse anaphoricity (de de Hoop 2003, 205)

A DP is anaphoric iff it refers to an object that has previously been mentioned in the discourse, and/or is part of the common ground.

Discourse anaphors access the previous discourse and enable, among other things, the pronominal reference. Personal pronouns are typical discourse anaphors, but expressions such as joku, 'somebody' and kuka tahansa 'whoever' are not. Let us assume that the discourse anaphoricity is encoded by the feature $[+\mathrm{d}]$ on the relevant element. Familiar topics as presented by Frascarelli \& Hinterhölzl (2007) are discourse anaphoric. I will argue in this 
paper that discourse anaphoricity is involved in movement to SpecFinP in Finnish (López 2009) but cannot alone explain the observed data.

The final discourse notion considered in this paper is contrast. Both topical elements and elements bearing new information can be contrasted in Finnish (É. Kiss 1998; Zubizarreta 1998; Vilkuna 1995; Vallduví \& Vilkuna 1998; Molnár 2006, among others). Contrasted elements are typically prosodically emphasised and they may be moved to the left periphery of the finite clause, to a projection above FinP, as in (8a) (Hakulinen \& Karlsson 1979). ${ }^{6}$

(8) a. [OpP MERJAA [FinP Pekka rakastaa]].
Merja.PAR Pekka.NOM love.PRES.3SG
'It's Merja that Pekka loves.'
b. Pekka rakastaa MERJAA.
Pekka.NOM love.PRES.3sG Merja.PAR
'It's Merja that Pekka loves.'/'Pekka loves MERJA.'

It should be mentioned that the terminology used for the information structure varies in the different theories of Finnish syntax. Some authors such as Hakulinen \& Karlsson (1979) and Holmberg (1998) use the term "focus" for referring to contrastively focused constituents, while. e.g., Holmberg \& Nikanne (2002), use the same term to indicate whether an element is old or new information. These two concepts of focus are not the same, as discussed in Kaiser (2006). I will use the term "contrast" as used by Vallduví \& Vilkuna (1998) (kontrast): If a given expression is contrastive, then a set of alternatives is generated and becomes available for semantic computation as a quantificational domain (Vallduví \& Vilkuna 1998, 83). In addition, contrast is assumed to be an independent feature (Neeleman et al. 2009).

The following section briefly outlines how prosody interacts with word order in Finnish.

${ }^{6}$ The fronted object argument is not necessarily prosodically emphasised in (8a), but this typically requires placing prosodic emphasis elsewhere in the sentence, as in Merjaa Pekka RAKASTAA 'It's Merja who Pekka LOVES'. We will leave this construction aside here and concentrate on the SpecFinP. 


\subsection{Basic word order and prosody in Finnish}

The basic word order of Finnish finite clauses is SVO. According to Välimaa-Blum (1993), the neutral prosodic pattern in spoken Finnish is a gradually declining pattern of $\mathrm{L}+\mathrm{H}^{*}$ accents and the final position has a low boundary tone (L\%). Let us assume that the neutral prosodic pattern reflects the neutral information structure encoded by the word order. I will follow Vilkuna (1989) and assume that the basic pattern appears in sentences in which the preverbal element is topical and the postverbal element is new information, as in (9a). The word order OVS can have the neutral prosodic pattern when the subject is new information (9b) (e.g., Välimaa-Blum 1988). ${ }^{7}$

(9) a. Minä ostin tuon kirjan.

I.NOM buy.PST.3SG that.ACC book.ACC

'I bought that book.'

b. Tuon kirjan osti opiskelija. that.ACC book.ACC buy.PST.3SG student.NOM

'A student bought that book.'

A proper name or a pronominal subject is typically prosodically prominent when it occurs in a low position, as in (10a). When the prosodic emphasis is strong, the subject is interpreted as contrasted, as in (10b). In this paper, contrasted elements are indicated with capital letters. Any emphasis that is less strong is not indicated in the examples.

(10) a. Sen osti Pekka.

it.ACC buy.PST.3SG Pekka.NOM

'Pekka bought it./It was bought by Pekka.'

b. Sen osti PEKKA (eikä kukaan muu).

it.ACC buy.PST.3SG Pekka.NOM not.and no-one else

'It was Pekka who bought it (not anyone else).'

We currently lack a comprehensive account of the relationship between the prosody and information structure of Finnish, and I will therefore mostly use other clues for examining the information content of expressions.

${ }^{7}$ Sentence (9a) has an additional possible reading in which the subject is new information. With this reading, the subject is typically prosodically prominent (Suni 2008). 


\section{Earlier accounts of movement to SpecFinP in Finnish}

Previous approaches to Finnish SpecFinP fall into three groups. The first group consists of approaches in which SpecFinP (or some other position corresponding to SpecFinP in the respective theory) is dedicated to the subject argument, and the other word orders are derived by displacement rules (Hakulinen \& Karlsson 1979; Välimaa-Blum 1988; Mitchell 1991; Holmberg et al. 1993; Brattico \& Huhmarniemi 2006). The second group contains approaches in which movement to SpecFinP involves a grammatical EPP movement independent of discourse (Vainikka 1989; Vainikka \& Levy 1999; Brattico 2016). In the third group are approaches that explain the movement by relying on discourse properties of the expressions (e.g., Välimaa-Blum 1988; Vilkuna 1989; Koskinen 1998; Holmberg \& Nikanne 2002; Jokilehto 2017). We will here concentrate on the approaches in the third group.

The aim is to show that movement to SpecFinP cannot be explained by relying only on discourse notions. Topicality is discussed in section 3.1, referentiality, familiarity and discourse anaphoricity in section 3.2 , non-focus in section 3.3, and definiteness in section 3.4. Section 3.5 summarises the observations.

\subsection{Topicality}

Koskinen $(1998,42)$ proposes that the left periphery of the Finnish finite clause contains the projection TopicP that hosts the aboutness topic of the utterance. The TopicP occurs below the FocusP that hosts wh-elements and contrasted constituents, as in (11).

(11) [CP [FocusP Contrast/wh [TopicP Topic [NegP [TP ... ]I]]]

Reinhart introduces the following tests for aboutness topics (rephrased by López 2009): (1) Topics can be introduced by the expression 'as for'; (2) topics can be introduced by the expression 'she said about'; (3) topics are referential; (4) presentational and existential sentences have no topics; and (5) topics carry existential presupposition. The main problem with the proposal by Koskinen (1998) is that there are many contexts in which the subject cannot be associated with the properties that characterise aboutness topics. For example, the subject can escape the first and second tests by Reinhart (1981), as illustrated in examples (12a) and (b). 
(12) a. Mitä tulee tähän kirjaan, Graham Greene kirjoitti sen. what comes this.to book.to G. G.NOM wrote it.ACC 'As for this book, Graham Greene wrote it.'

b. Merja sanoi tästä kirjasta, että Graham Greene kirjoitti sen. Merja said this.from book.from that G. G.NOM wrote it.ACC "Merja said about this book that Graham Greene wrote it.'

Vilkuna (1989, 79-84) suggests that topic entity is associated with the Tfield as a strategical rule, not as an obligatory rule. In addition, she states that the two discourse fields at the left periphery (T-field and K-field) "are compromises between discourse and syntactic categories rather than pure discourse concepts" (ibid., 38). Instead of assuming that only topics move to SpecFinP, it is common to assume that the element that moves to SpecFinP possesses a property that meets some essential requirement for topics.

The following section considers referentiality (property (3)) and the existential presupposition (property (5)). Presentational and existential sentences are not discussed in this paper.

\subsection{Referentiality, familiarity, and discourse anaphoricity}

According to the property (3) of topics proposed by Reinhart (1981), topic has to be referential (Chafe 1976). However, the subject argument in examples such as (13a-b) does not pass this test. Moreover, example (c) shows that the subject may occupy SpecFinP even if it does not carry existential presupposition (see also Hakulinen et al. 2004, §1372), which was the property (5) of sentence topics in Reinhart (1981). The phrase ilmeisesti 'apparently' has been inserted in the examples to indicate that the higher structural position is filled and the subject argument thus occupies SpecFinP (e.g., Vilkuna 1989; Manninen 2003).

(13) a. Mitä tähän lauluun tulee, kuka tahansa oppii sen. what this.to song.to comes who.NOM ever learn.PRES.3SG it.ACC

'As for this song, anyone can learn it.'

b. Ilmeisesti kuka tahansa oppii sen. apparently who.NOM ever.NOM learn.PRES.3SG it.ACC 'Apparently anyone can learn it.'

c. Ilmeisesti kukaan ei oppinut sitä. apparently no-one.NOM not.3SG learn.PST.SG it.PAR 'Apparently no-one was able to learn it.' 
Holmberg (2010) notes that examples such as those above form a problem for approaches that assume that the element in SpecFinP should be capable of functioning as a topic. He mentions that referentiality could nevertheless be a trigger for movement for other elements than subjects: "A closer approximation to the truth is that the subject may check the EPP even if it is not referential, but, for example, a quantified NP, while non-subjects have to be referential and interpretable as topics, to check the EPP" (ibid., 213).

Another piece of evidence against the proposal that referentiality triggers movement to SpecFinP is offered by the derivation of wh-questions such as $(14 a-b)$. Assuming that the EPP is in effect in Finnish, the derivation of sentences (14a) and (b) must involve a step where SpecFinP is occupied by a wh-phrase. A derivational theory of word order cannot therefore rule out the possibility that non-referential elements, such as wh-phrases, occupy SpecFinP.
(14) a. Kuka osti kirjan?
'Who bought a/the book?'
who.NOM buy.PST.3SG book.ACC
b. Mitä osti Pekka?
what.PAR buy.PST.3SG Pekka.NOM
'What did Pekka buy?'

López (2009) proposes that movement to SpecFinP is triggered by discourse anaphoricity. He suggests that $[+\mathrm{d}]$ is responsible for OVS word order, for example, in the Finnish finite clause (15).
(15) Mervin tapasi
Seija.
Mervi.ACC meet.PST.3SG Seija.NOM
'Mervi was met by Seija.'

López (2009) does not address movement of the subject argument, which cannot be accounted for by relying on $[+\mathrm{d}]$, as we have seen in this section.

Another, related concept that has been attributed to topics is specificity (É. Kiss 1995; for Finnish, see Jokilehto 2017). The examples presented in this section suggest that specificity is not sufficient for explaining movement to SpecFinP in Finnish (see also Koskinen 1998, 46-47). For the same reason, the subject argument cannot be a familiar topic in the classification according to Frascarelli \& Hinterhölzl (2007). 


\subsection{Non-focus}

Holmberg \& Nikanne (2002) put forward an approach in which elements that are not new information move outside the $v \mathrm{P}$ and in which one of these elements moves overtly to SpecFinP (SpecFP in their terminology). Holmberg \& Nikanne make use of the feature $[ \pm$ Foc $]$, where $[+$ Foc $]$ indicates 'information focus' of the sentence in the sense of (Vallduví \& Engdahl 1996). They propose that the EPP feature of the head F (here Fin) attracts elements with the feature [-Foc]. The distinction between $[+\mathrm{Foc}]$ and $[-\mathrm{Foc}]$ corresponds roughly to the concepts of new and old information (see the discussion in Kaiser 2006).

The proposal of Holmberg \& Nikanne (2002) is called into question by examples such as (16). In an answer to a wh-question, the element that replaces the wh-phrase is considered new information, hence bearing the feature [-Foc] (Lambrecht 1994). Both the answer A1, where the subject occupies SpecFinP, and the answer A2, where the subject is in situ, qualify as answers to the question. ${ }^{8}$ Dal Pozzo (2012) has shown in an experimental study that the preferred answering strategy for questions such as (16) is $\mathrm{SV}(\mathrm{O})$, which means that the subject moves to SpecFinP also when it has $[+$ Foc $]$.

(16) Kuka osti tämän lehden?

'Who bought this paper?'

A1: Pekka osti sen.

Pekka.NOM buy.PST.3sG it.ACC

'Pekka bought it.'

A2: Sen osti Pekka.

it.ACC buy.PST.3SG Pekka.NOM

'It was bought by Pekka.'

${ }^{8}$ Note that this test applies only for the subject argument. For example, the object argument that conveys new information cannot move to SpecFinP in answers to (i).

(i) Mitä Pekka osti?

'What did Pekka buy?'

A1: \#ämän lehden osti Pekka.

this.ACC paper.ACC buy.PST.3SG Pekka.NOM

A2: Pekka osti tämän lehden.

Pekka.NOM buy.PST.3SG this.ACC paper.ACC

'Pekka bought this paper.' 
Thus, although associating new information with the nominative subject enables it to stay in situ in the answer A2 above, it does not prevent movement. In addition, the subject can be right-dislocated (17a) or 'floated' around the structure (b) (Brattico 2016).

(17) a. Tämän kirjan halusi ostaa Pekka.

this.ACC book.ACC want.PST.3SG buy.INF Pekka.NOM

'It was Pekka who wanted to buy this book.'

$\begin{array}{llll}\text { b. Tämän kirjan (Pekka) halusi } & \text { (Pekka) ostaa (Pekka). } \\ \text { this.ACC book.ACC } & \text { want.PST.3SG } & \text { buy.INF }\end{array}$

'It was Pekka who wanted to buy this book.'

I conclude that the feature that triggers movement of the subject cannot be non-focus [-Foc]. Nevertheless, it seems that the subject does not have to move to SpecFinP if it is new information (or contrasted).

\subsection{Definiteness}

The final discourse property considered here is definiteness. Välimaa-Blum (1988) proposes that Finnish subject NPs in the final position are interpreted as indefinite (IdentIndef) while NPs in SpecFinP are definite (IdentDef). This generalisation is assumed to apply both to subjects and other elements that move to SpecFinP. One example discussed by Välimaa-Blum $(1988,81-83)$ is provided in $(18 \mathrm{a}-\mathrm{b})$, where the NP käärme 'snake' is indefinite. It is proposed that the word order in (18a) is the only neutral order for this sentence and that sentence (b) is marked.

On the other hand, if käärme 'snake' is interpreted as definite, then sentence (b) is unmarked.
(18) a. Minua puri käärme.
I.PAR bite.PST.3SG snake.NOM
'I was bitten by a snake.'
b. Käärme puri minua. snake.NOM bite.PST.3SG I.PAR
'A/the snake bit me.'

Yet, I find the example (18b) to be only slightly marked. Similar examples in which an indefinite subject occupies SpecFinP are common in different contexts; one such example is provided in (19). ${ }^{9}$

${ }^{9}$ http://www.tiede.fi/keskustelu/33321/ketju/superelamykselliset_unet_painajaiset 
(19) Internet

Näin unen, jossa käärme puri minua [...].

saw.PST.1SG dream.ACC which.in snake.NOM bite.PST.3SG I.PAR

'I dreamt that a snake bit me [...]'

Thus, movement to SpecFinP does not determine the interpretation of plain NPs as definite or indefinite although it may have an effect on the preferred interpretation of the NP (for a discussion of indefinite topics, see Erteschik-Shir 2013). In addition, definiteness cannot be seen as a criterion for the movement of the subject, as can be seen in examples (13). Välimaa-Blum acknowledges this and suggests that specific marking of definiteness/indefiniteness and/or intonation may override the effect of the word order.

\subsection{Summary}

Section 2 investigated topicality, referentiality, familiarity, discourse anaphoricity, non-focus, and definiteness as triggers of movement to the Finnish SpecFinP position. It was shown that the subject can move to SpecFinP even if it does not possess any of these properties. These observations motivate the proposal that movement to SpecFinP is an instance of formal EPP movement, which is neutral to discourse.

However, it is not without reason that SpecFinP has been considered to be a discourse position. There is a tendency in Finnish to place discourse-old elements at the beginning of the sentence (e.g., Chesterman 1991; Hiirikoski 1995; Helasvuo 2001). To resolve this discrepancy, I propose that movement to SpecFinP in transitive clauses involves an intermediate movement step to the edge of $v \mathrm{P}$ for other than subjects and certain adverbials. This movement is an instance of scrambling, and triggered by discourse anaphoricity. This means that although the EPP itself is discourse neutral, it reflects the discourse properties of an earlier movement that feeds the EPP.

\section{Scrambling to the edge of $v \mathrm{P}$ in Finnish}

This section presents the background for a model in which the subject argument reaches SpecFinP via one EPP movement, as in (20a), but the object argument has to move to the edge of $v \mathrm{P}$ in order to be selected for EPP movement as in (b). Thus, while the EPP movement to SpecFinP 
is discourse neutral for both arguments, the object argument undergoes discourse induced scrambling prior to the EPP.

(20) a. Movement of the subject

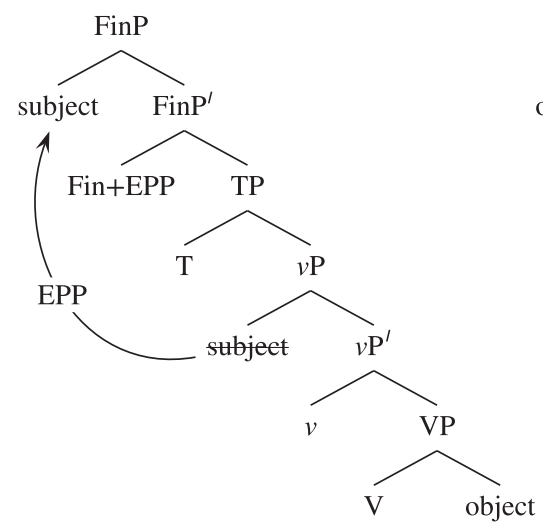

b. Movement of the object argument

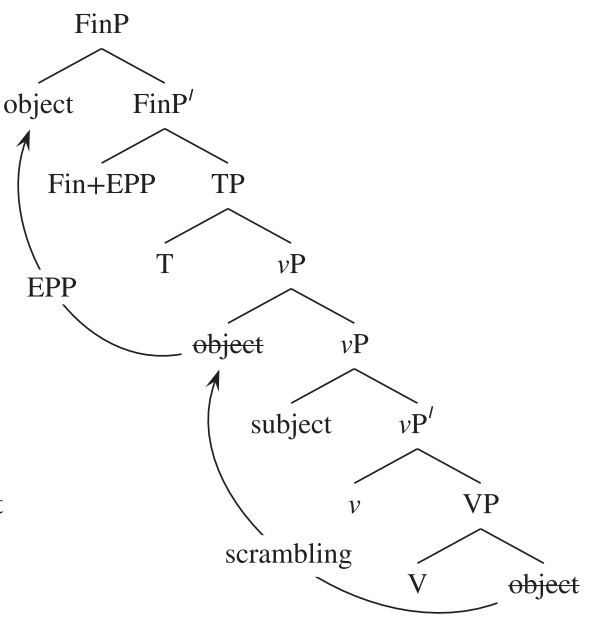

I propose relying on the previous research on the derivation of OV order in Finnish, that scrambling to the edge of $v \mathrm{P}$ in (20b) is triggered by discourse anaphoricity (Boef \& Dal Pozzo 2012 see also Vilkuna 1989; 2014; Kaiser \& Trueswell 2004).

The following section discusses the derivation of OV order in Finnish as presented in the previous literature. Although the discussion is limited to the object argument, scrambling to the edge of $v \mathrm{P}$ is tentatively assumed to extend to other $v \mathrm{P}$ internal elements, such as indirect objects. Scrambling to the edge of $v \mathrm{P}$ as a pre-requisite for the EPP is discussed in section 4.2.

\subsection{Derivation of OV order in Finnish}

Although Finnish typically exhibits SVO word order, SOV order is fairly common for expressing discourse-related meanings. However, OV order does not alternate freely with VO in Finnish and is instead associated with sentence initial focus (Hakulinen \& Karlsson 1979; Välimaa-Blum 1988; Vilkuna 1989; 1995; Holmberg 2000). Whereas it is impossible to move the object DP past the subject as in (21b), the movement becomes possible if 
the left periphery of the finite clause contains a contrasted constituent as in (c). ${ }^{10}$
(21) a. Jussi on kirjoittanut tuon romaanin. Jussi.NOM be.PRES.3SG write.PST.SG that.ACC novel.ACC 'Jussi has written that novel.'
Jussi.NOM be.PRES.3SG that.ACC novel.ACC write.PST.SG
c. Jussi on tuon romaanin kirjoittanut -
b. " Jussi on tuon romaanin kirjoittanut
Jussi.NOM be.PRES.3SG that.ACC novel.ACC write.PST.SG
'JUSSI has written that novel.'

According to Vilkuna (1989), a V-complement that occupies a preverbal position cannot convey the main news of the sentence. Thus, an object argument that bears new information cannot be scrambled in front of the verb. Holmberg (2000) argues that the Finnish restriction on OV word order is related to the (universal) observation that each sentence has to contain at least one instance of new information. In Finnish, the locus of new information is associated with postverbal constituents. ${ }^{11}$ This means that scrambling of the postverbal constituent is restricted unless the finite clause contains another locus of new information.

Along the same lines, Boef \& Dal Pozzo (2012) propose that the object is base-generated to the complement of the verb and has to stay in-situ when it expresses new information. ${ }^{12}$ In addition, they connect the movement of the object with discourse anaphoricity. The two positions for the object argument are illustrated in (22). The phenomenon is also discussed in Koskinen (1998); Kaiser \& Trueswell (2004); Kaiser (2006); Schmidt (2016) and Jokilehto $(2017,119)$.

$\begin{array}{lll}\text { (22) Jussi kirjan } & \text { luki kirjan. } \\ \mathrm{S}_{\mathrm{FOC}} \mathrm{O}_{\text {D-linked/*NEW }} \mathrm{V} & \mathrm{O}_{\text {D-linked/NEW }}\end{array}$

(Boef \& Dal Pozzo 2012, 54)

The idea that constructions with OV in Finnish relate to previously mentioned information is not new; Vilkuna (2014) notes that this phenomenon was first described in Lindén (1959). According to Vilkuna (2014, 199),

\footnotetext{
${ }^{10}$ Wh-phrases and relative pronouns at the left periphery also enable the OV word order.

${ }^{11}$ Koskinen (1998, 92-93) proposes that there is a ban on the $v \mathrm{P}$ being completely empty, which would restrict the movement of object arguments.

12 See Holmberg (2000) for an alternative approach.
} 
"The typical XV instances all share the function of referent or situation identification; to do this, they operate on information that is under discussion or that is at least entertained in the context". The feature discourse anaphoricity may thus be seen as a partial formalisation of the phenomenon.

Let us finally consider the landing site of the object argument. Scrambling of a direct object is typically observed in the relative ordering of the object argument, the verb, and a sentential adverb. For example, sentences such as (23a), in which the adverbial occurs above the object argument, support the analysis that the object has been scrambled to the edge of $v \mathrm{P}$ and the verb does not move. However, both elements may also precede the adverbial $(b-c)$. It thus seems that these elements may occupy a higher position in the structure, or, alternatively, that the position of the adverbial is allowed to vary. ${ }^{13}$

(23) a. Jussi on eilen tuon romaanin kirjoittanut.

Jussi.NOM be.PRES.3SG yesterday that.ACC novel.ACC write.PST.SG

'Jussi has written that novel yesterday.'

b. Jussi on tuon romaanin eilen kirjoittanut.

Jussi.NOM be.PRES.3SG that.ACC novel.ACC yesterday write.PST.SG

c. Jussi on tuon romaanin kirjoittanut eilen.

Jussi.NOM be.PRES.3SG that.ACC novel.ACC write.PST.SG yesterday

Using the position of the adverbial as a diagnostics is problematic in Finnish for two reasons. First, the finite verb typically moves to Fin $^{0}$ in Finnish, and it has turned out to be difficult to point out contexts where the verb would reliably occur within the $v \mathrm{P}$ (Schmidt 2016). On the other hand, the position of the sentential adverb is very flexible in Finnish, and thus the example (23c) may be an instance of a "floating" adverbial (Brattico 2016). ${ }^{14}$ For example, Koskinen (1998) proposes that presupposed DPs are moved out of the verb phrase and that these DPs can be adjoined to some of the functional projections higher in the clause, such as vP, TP, or TopicP.

For the purposes of this paper, it suffices to assume that the object argument moves to a higher position, out of the complement of VP. This

13 The prosodic emphasis is this time not indicated in the examples, since there are several options to prosodically emphasise different elements and more research is needed to establish their information structural status.

${ }^{14}$ For a comparison between Finnish scrambling and scrambling in Dutch and other Germanic languages see Holmberg (2000); Boef \& Dal Pozzo (2012); Schmidt (2016). 
position can be the spec, $v \mathrm{P}$ or a specifier of a higher functional projection. For example, Jokilehto (2017) assumes that all m-marked constituents occupy the specifier of a (recursive) projection PEMP, located above $v \mathrm{P}$.

Finally, according to Kaiser (2002), Finnish ditransitive constructions may involve scrambling of discourse-old elements upwards in the structure. In Kaiser's analysis of ditransitives, the base-generated word order is direct object (DO) - indirect object (IO), as in (24a). The order IO-DO in (b) is derived by scrambling the indirect object to a position outside the VP (see Manninen 2003, for an alternative analysis).

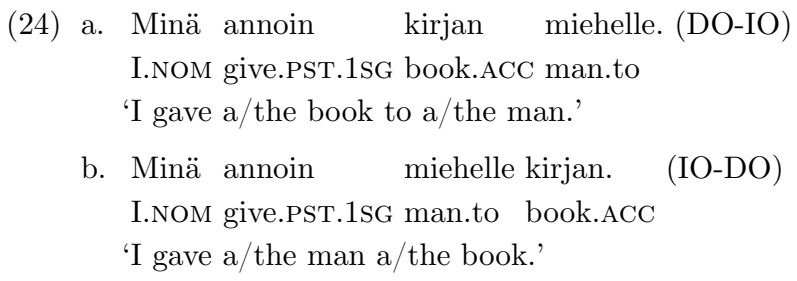

Kaiser also notes that the scrambling observed in ditransitive clauses and movement to SpecFinP might be triggered by the same features, although she does not develop this idea further. In the following section, we propose that this feature is involved in the scrambling of the object argument to the edge of $v \mathrm{P}$, which is also a partial implementation for movement to SpecFinP.

\subsection{Scrambling to the edge of $v P$}

In this section, I propose that movement of a discourse anaphoric object (or other element) to SpecFinP in Finnish has an intermediate landing site in the specifier of $v \mathrm{P}$. In order for an object argument to occupy the specifier of $v \mathrm{P}$, it has to move past the subject argument. This movement displays intervention effects in contexts where the two elements have the same discourse feature specification.

The first example of an intervention effect is provided in $(25 \mathrm{a}-\mathrm{c})$. In example (b), a the pronominal $[+d]$ object cannot be moved past the pronominal $[+\mathrm{d}]$ subject unless the in-situ subject is contrasted or ostensive. The example (c) shows that when the subject can be interpreted as $[-\mathrm{d}]$, the object is able to move past it.
(25) a. Hän tapasi minut.
s/he.NOM meet.PST.3SG I.ACC
'He/she met me.' 
b. Minut tapasi H H ÄN $/{ }^{*}$ hän.

I.ACC meet.PST.3SG s/he.NOM

'I was met by HIM/HER.'

c. Minut tapasi opettaja.

I.ACC meet.PST.3SG teacher.NOM

'I was met by a teacher.'

Vilkuna (1989) provides the following generalisation that applies to this phenomenon:

(26) Generalisation for phrases with equal information status (Vilkuna 1989, 66)

If two adjacent phrases $\mathrm{A}$ and $\mathrm{B}$ are equal in information status (both old or both new), their mutual order reflects their syntactically unmarked order.

This is one way of capturing the intervention effect caused by discourse properties of the elements observed in examples (25). In this paper, we use the locality condition Attract Closest in (27) (modified from Chomsky 1995).

\section{(27) Attract Closest}

The head $\mathrm{H}$ attracts the closest element with relevant features to its specifier position.

$\mathrm{Y}$ is closer to $\mathrm{H}$ than $\mathrm{Z}$ if $\mathrm{H}$ c-commands $\mathrm{Y}$ and $\mathrm{Y}$ c-commands $\mathrm{Z}$.

A node X c(onstituent)-commands its sibling and all the sibling's children.

It thus seems that the pronominal $[+\mathrm{d}]$ subject blocks movement of the pronominal $[+\mathrm{d}]$ object. To illustrate this condition further, consider examples $(28 \mathrm{a}-\mathrm{b})$. In the given context, the subject Seija, as well as the other participants, are familiar from discourse, hence $[+\mathrm{d}]$. Example $(\mathrm{b})$ shows that the object cannot move past the discourse-old subject unless the subject is contrasted. ${ }^{15}$

${ }^{15}$ What happens if both the subject and the object are $[-\mathrm{d}]$ and the EPP is obligatory? Again, Vilkuna's observation (26) holds: phrases with equal information status tend not to move past each other. Examples (ia-b) show that an element with $[-d]$ cannot move past the subject with $[-\mathrm{d}]$.

(i) a. Kuka tahansa ostaa _ mitä tahansa. who.NOM ever buy.PRES.3SG what.PAR ever

'Anyone buys anything.'

b. *Mitä tahansa ostaa kuka tahansa _. what.PAR ever buy.PRES.3SG who.NOM ever 
(28) a. Seija, Anne, Jukka ja Mervi olivat täällä.

Seija Anne Jukka and Mervi be.PST.3PL here.at

'Seija, Anne, Jukka, and Mervi were here.'

b. Seija tapasi Mervin ensimmäistä kertaa.

Seija.NOM meet.PST.3SG Mervi.ACC first time

'Seija met Mervi for the first time.'

c. Mervin tapasi SEIJA/*Seija ensimmäistä kertaa.

Mervi.ACC meet.PST.3SG Seija.NOM first time

'Mervi was met by SEIJA for the first time.'

Another interesting example of a constraint on scrambling is provided in (29a-b) by Holmberg $(2010,213)$. The DP kenelle tahansa 'to whoever' cannot move to SpecFinP. ${ }^{16}$ In this example, kenelle tahansa 'to whoever' is $[-\mathrm{d}]$ and the proper name subject can be either $[+\mathrm{d}]$ or $[-\mathrm{d}]$. If the subject is $[+d]$, the indirect object cannot move past it. However, if both elements are [-d], the subject still moves, because it is a closer potential element that can satisfy the EPP. The only available order is thus (b). Finally, there is an option to generate an expletive to SpecFinP (c). ${ }^{17}$

(29) a. *Kenelle tahansa puhuu Aila.

who.to ever talk.PRES.3SG Aila.NOM

b. Aila puhuu kenelle tahansa.

Aila.NOM talk.PRES.3SG who.to ever

'Aila talks to anyone.'

${ }^{16}$ It should be noted that auxiliaries enable more word order variation (i):

(i) ?Imeisesti kenelle tahansa voi Aila puhua.

apparently who.to ever can.PRES.3SG Aila talk.INF

'Apparently Aila can speak to anyone.'

17 The problem with sentence (ia) is not likely to be two disjoint foci as mentioned in (Holmberg 2010, 213, fn. 17), since the in situ object in A1 can be new information, or the sentence can contain two phrases that are equally non-referential A2.

(i) Mitä oppii helposti?

what.PAR learn.PRES.3SG easily

'What does one learn easily?'

A1: Kuka tahansa oppii tämän laulun helposti. who.NOM ever learn.PRES.3SG this.ACC song.ACC easily

'Anyone can easily learn this this song.'

A2: Kuka tahansa oppii mitä tahansa.

who.NOM ever.NOM learn.PST.3SG what.PAR ever.PAR

'Anyone can learn anything.' 

c. Sitä puhuu Aila kenelle tahansa. EXPL talk.PRES.3SG Aila.NOM who.to ever 'Aila talks to anyone'

Note that sentence (29a) improves when the subject is contrasted, as in (30). This is as predicted above, for the contrasted constituent now has a different discourse feature specification than the moving element.
(30) a. 'Kenelle tahansa puhuu vain Aila.
who.to ever talk.PREs.3SG only Aila.NOM
'Only Aila talks to anyone.'
b. 'Kenelle tahansa osaa puhua AILA, ei Pekka. who.to ever can.PRES.3SG talk.INF Aila.NOM not.3SG Pekka.NOM 'It's Aila who can talk to anyone, not Pekka.'

In conclusion, this section shows that movement to SpecFinP displays intervention effects that are argued to arise from scrambling within the $v \mathrm{P}$. The subject argument occupies the specifier of $v \mathrm{P}$ and causes an intervention effect for movement of other elements past it.

\section{The proposed model}

This section summarises the basic findings of this paper and how they support the model proposed here. First, it was shown in section 3 that existing discourse-based theories of movement to SpecFinP in Finnish fail to account for the movement of the subject. Contrary to these theories, it is argued that the movement to SpecFinP is an instance of formal EPP movement probed by the Fin head. The EPP is not sensitive to discourse; it can target any referential category (Holmberg 2005), and it follows the locality condition Attract Closest (27). Movement of the subject argument is illustrated in (31a). In basic transitive and unergative clauses, the subject occupies the specifier of $v \mathrm{P}$ and is therefore the closest potential goal for EPP movement.

Nevertheless, the proposal that the EPP is discourse neutral fails to account for the tendency of SpecFinP to host discourse-old elements (Chesterman 1991; Hiirikoski 1995). To explain this dilemma, it is proposed that the object argument has to first move to the edge of $v \mathrm{P}$, past the subject argument, in order to be available for the EPP. This movement is an instance of scrambling triggered by discourse anaphoricity, similar to what is observed in the derivation of OV word order in Finnish. 
These processes explain the variation observed in movement to SpecFinP. While the subject argument reaches the SpecFinP in one step (31a), the movement of the object argument proceeds in two (or more) steps (b).

(31) a. Movement of the subject

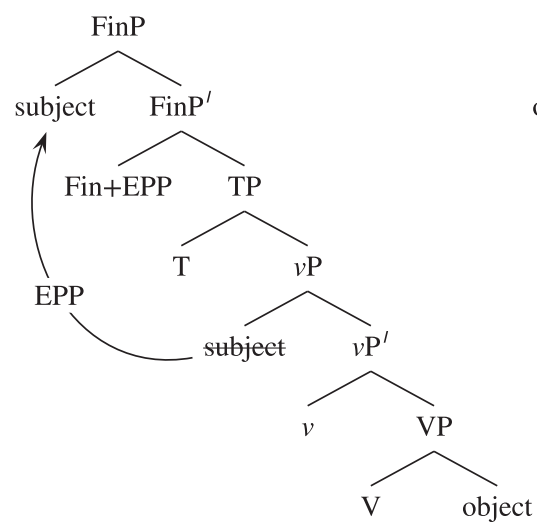

b. Movement of the object argument

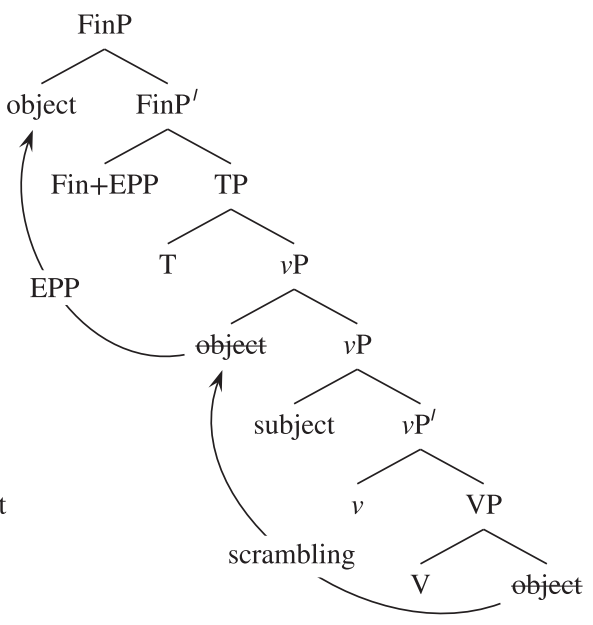

I propose that one of the features that triggers scrambling of the object argument is discourse anaphoricity $[+\mathrm{d}]$. In addition, scrambling obeys the locality condition Attract Closest, which causes intervention effects in contexts where a constituent is moved past another constituent with the same feature specification (Rizzi 1990).

This model accounts for the observation that SpecFinP displays both A- and A'-properties in Finnish (Holmberg \& Nikanne 2002). The A-properties are associated with the movement of the subject, and the $\mathrm{A}^{\prime}$-properties arise from the $v \mathrm{P}$-internal scrambling of other elements. Furthermore, Helasvuo $(2001,79-81)$ has observed in the spoken data that pronominal $[+\mathrm{d}]$ subjects precede the verb more often than other noun phrases do. This phenomenon is explained by assuming that the pronominal subject at the specifier of $v \mathrm{P}$ causes an intervention effect for scrambling of the object and thus prevents other elements from reaching the SpecFinP.

Another interesting prediction concerns the movement of pro-subjects to SpecFinP. In Finnish, a pro-subject necessarily moves to SpecFinP, as in (32a) (Hakulinen 1976; Vainikka \& Levy 1999; Holmberg 2005). It requires an antecedent either in the local domain (3rd person pro-elements) or in the immediate context (1st and 2 nd person pro-elements). It is therefore justified to assume that pro has the property $[+\mathrm{d}]$. In example $(32 \mathrm{~b})$, the direct object is contrastive, which suggests that the pro-element is in 
SpecFinP. The feature $[+\mathrm{d}]$ on the subject prevents elements in the lower positions from moving past the subject to SpecFinP.
(32) a. pro Ostin tämän kirjan Merjalle.
buy.PST.1SG this.ACC book.ACC Merja.to
'I bought this book for Merja.'
b. TÄMÄN KIRJAN pro ostin Merjalle -
this.ACC book.ACC buy.PST.1SG Merja.to
'I bought THIS BOOK for Merja.'

We have seen that the subject can stay in situ if it is contrasted or carries new information. However, the Finnish pro-element is never contrasted because it is phonologically empty and cannot be prosodically emphasised. ${ }^{18}$ The model presented here thus accounts for the fact that the pro-subject has to move to SpecFinP in Finnish.

In addition, the model presented here is compatible with Chomsky's phase theory (Chomsky 2001). In the phase-based model of grammatical derivation, the derivation of an expression is divided into smaller substructures, called phases, and only the edge of each phase is visible for movement outside the phase. According to Chomsky (2001), at least CPs and $v$ Ps are phases. This means that in order for any element to move from inside $v \mathrm{P}$ to the specifier of FinP, the element must first occupy the edge of the $v \mathrm{P}$. An object argument would therefore not be visible for the EPP unless it occupies the edge of the $v \mathrm{P}$. This model predicts that languages without scrambling to the edge of $v \mathrm{P}$, such as English, would not have the option to move an object argument to SpecFinP. Nevertheless, the question whether

18 The pro-subject in SpecFinP cannot be new information in the answer A1 to the question (i). Only the overt subject is available in this context (answer A2). This suggests that a subject that has new information in SpecFinP is prosodically prominent, and this cannot be implemented with a pro-subject.

(i) Kuka osti tämän kirjan Merjalle?

who.NOM buy.PST.3SG this.ACC book.ACC Merja.to

'Who bought this book for Merja?'
A1: ${ }^{\prime}$ Ostin tämän kirjan Merjalle.
buy.PST.1SG this.ACC book.ACC Merja.to
A2: Minä ostin tämän kirjan Merjalle.
I.NOM buy.PST.1SG this.ACC book.ACC Merja.to
'I bought this book for Merja.' 
scrambling to the Spec $v \mathrm{P}$ is required for among others wh-movement, is left open here. ${ }^{19}$

The present approach is related to the one proposed by Hiraiwa (2001) for Scandinavian languages. Hiraiwa (2001) argues that the parametric differences between Scandinavian languages concerning, among others, the object shift can be explained by assuming that the EPP selects the closest potential goal. Furthermore, he proposes that the EPP can be contingent on phi-Agree in some languages, such as Icelandic, and therefore able to target a shifted object DP at the specifier of $v \mathrm{P}$.

\section{Conclusions}

This paper has examined movement to SpecFinP in Finnish. The investigation confirms previous observations about the role of the subject argument as the 'default' element in SpecFinP. The prominence of the subject in SpecFinP was explained for by assuming that the Fin head has a formal EPP property in Finnish, and by assuming that the EPP obeys the locality condition Attract Closest. The nominative agreeing subject is therefore the closest potential goal for the EPP, while the other elements have to first move past the subject to the edge of $v \mathrm{P}$ in order to be available for the EPP. It was proposed that movement to the edge of $v \mathrm{P}$ is an instance of scrambling that can be triggered among others by discourse anaphoricity. The model presented here accounts for the discourse properties of SpecFinP as reflections of an earlier, discourse-induced scrambling to an intermediate position in Spec $v$ P.

${ }^{19}$ For example, Chomsky (2001) and Kitahara (2002) have addressed the object movement to the edge of $v \mathrm{P}$ in order to account for the $\mathrm{A}^{\prime}$-movement of the wh-phrase under the condition of phase impenetrability condition. The wh-object has to move to the edge of $v \mathrm{P}$ in order to be visible for $\mathrm{A}^{\prime}$-movement later in the derivation. Both Chomsky (2001) and Kitahara (2002) discuss the problem that arises when the whobject moves past the wh-subject and causes an intervention effect for the movement of the subject in languages where the subject moves to SpecFinP. It was shown in this paper that in Finnish, the subject is an intervening element for scrambling of the object. 


\section{Acknowledgements}

I would like to thank the participants of the following events for insightful questions and comments: the Conference on the Syntax Of Uralic Languages (SOUL 2017) in Budapest, in June 2017, and the workshop Syntactic Structure of Uralic Languages organised in connection with the XII International Congress for Finno-Ugric Studies in Oulu, Finland, in August 2015. I am grateful to Pauli Brattico, Tommi Gröndahl, Jukka Purma and Taija Saikkonen for discussions about different aspects of Finnish word order. Thank you to Mark Norris and Andreas Schmidt for commenting an earlier version of the paper.

The research for this paper was financially supported by the Kone Foundation.

\section{References}

Bianchi, Valentina and Mara Frascarelli. 2010. Is topic a root phenomenon? Iberia 2. 43-88.

Boef, Eefje and Lena Dal Pozzo. 2012. Some notes on word order and interpretation in Dutch and Finnish. Nordlyd 39. 44-62.

Brattico, Pauli. 2016. Is Finnish topic prominent? Acta Linguistica Hungarica 63. 299-330.

Brattico, Pauli and Saara Huhmarniemi. 2006. Finnish negation, EPP and the valuation theory of morphosyntax. Nordic Journal of Linguistics 29. 5-44.

Brattico, Pauli, Saara Huhmarniemi, Jukka Purma and Anne Vainikka. 2014. The structure of Finnish $\mathrm{CP}$ and feature inheritance. Finno-Ugric Languages and Linguistics 2. 66-109.

Brody, Michael. 1995. Lexico-logical form. Cambridge, MA: MIT Press.

Chafe, Wallace L. 1976. Givenness, contrastiveness, definiteness, subjects, topics and point of view. In C. N. Li (ed.) Subject and topic. New York: Academic Press. 27-55.

Chesterman, Andrew. 1991. On definiteness. A study with special reference to English and Finnish. Cambridge: Cambridge University Press.

Chomsky, Noam. 1977. On wh-movement. In P. W. Culicover, T. Wasow and A. Akmajian (eds.) Formal syntax. New York: Academic Press. 71-132.

Chomsky, Noam. 1995. The minimalist program. Cambridge, MA: MIT Press.

Chomsky, Noam. 2000. Minimalist inquiries: The framework. In R. Martin, D. Michaels and J. Uriagereka (eds.) Step by step: Essays on minimalist syntax in honor of Howard Lasnik. Cambridge, MA: MIT Press. 89-155.

Chomsky, Noam. 2001. Derivation by phase. In M. Kenstowicz (ed.) Ken Hale: A life in language. Cambridge, MA: MIT Press. 1-52.

Dal Pozzo, Lena. 2012. New information subjects in Finnish: An experimental study. FinnoUgric Languages and Linguistics 1. 67-81.

Dijk, Teun Adrianus, van. 1977. Text and context: Explorations in the semantics and pragmatics of discourse. London: Longman.

É. Kiss, Katalin (ed.). 1995. Discourse configurational languages. Oxford: Oxford University Press.

É. Kiss, Katalin. 1998. Identificational focus versus information focus. Language 74. $245-273$. 
Erteschik-Shir, Nomi. 2013. Information structure and (in)definiteness. In P. C. Hofherr and A. Zribi-Hertz (eds.) Crosslinguistic studies on noun phrase structure and reference. Leiden \& Boston: Brill, Syntax and Semantics 39. 23-51.

Frascarelli, Mara and Roland Hinterhölzl. 2007. Types of topics in German and Italian. In K. Schwabe and S. Winkler (eds.) On information structure, meaning and form. Amsterdam \& Philadelphia: John Benjamins. 87-116.

Frey, Werner. 2004. A medial topic position for German. Linguistische Berichte 198. 153-90.

Hakulinen, Auli. 1976. Liitepartikkelin -han/hän syntaksia ja pragmatiikkaa [The syntax and pragmatics of the Finnish clitic -han/-hän]. Turku: Abo Akademi Forskningsinstitut.

Hakulinen, Auli and Fred Karlsson. 1979. Nykysuomen lauseoppia [Syntax of Modern Finnish]. Helsinki: Finnish Literature Society.

Hakulinen, Auli, Maria Vilkuna, Riitta Korhonen, Vesa Koivisto, Tarja Riitta Heinonen and Irja Alho (eds.). 2004. Iso suomen kielioppi [A comprehensive grammar of Finnish]. Helsinki: Finnish Literature Society.

Heinämäki, Orvokki. 1984. Aspect in Finnish. In C. de Groot and H. Tommola (eds.) Aspect bound: A voyage into the realm of Germanic, Slavonic and Finno-Ugrian aspectology. Foris: Dordrecht. 207-234.

Helasvuo, Marja-Liisa. 2001. Syntax in the making: The emergence of syntactic units in Finnish conversation. Amsterdam \& Philadelphia: John Benjamins.

Hiirikoski, Juhani. 1995. Organization in discourse. In B. Wårwik, S.-K. Tanskanen and R. Hiltunen (eds.) Proceedings of the Turku Conference (Anglicana Turkuensia). 289-299.

Hiraiwa, Ken. 2001. EPP and object shift in the Scandinavian languages. Paper presented at the Comparative Germanic Syntax Workshop (CGSW16).

Holmberg, Anders. 1998. Word order variation in some European SVO languages: A parametric approach. In Constituent order in the languages of Europe. Berlin \& New York: Mouton de Gruyter. 553-598.

Holmberg, Anders. 2000. Scandinavian stylistic fronting: How any category can become an expletive. Linguistic Inquiry 31. 445-483.

Holmberg, Anders. 2005. Is there a little pro? Evidence from Finnish. Linguistic Inquiry 36. 533-564.

Holmberg, Anders. 2010. The null generic subject pronoun in Finnish: A case of incorporation in T. In T. Biberauer, A. Holmberg, I. Roberts and M. Sheehan (eds.) Parametric variation: Null subjects in Minimalist Theory. Cambridge: Cambridge University Press. 200-230.

Holmberg, Anders and Urpo Nikanne. 2002. Expletives, subjects and topics in Finnish. In P. Svenonius (ed.) Subjects, expletives, and the EPP. Oxford: Oxford University Press. $71-106$.

Holmberg, Anders, Urpo Nikanne, Irina Oraviita, Hannu Reime and Trond Trosterud. 1993. The structure of INFL and the finite clause in Finnish. In A. Holmberg and U. Nikanne (eds.) Case and other functional categories in Finnish syntax. Berlin \& New York: Mouton de Gruyter. 177-206.

Hoop, Helen, de. 2003. Scrambling in Dutch: Optionality and optimality. In S. Karimi (ed.) Word order and scrambling. Malden, MA \& Oxford: Blackwell. 201-216. 
Huhmarniemi, Saara. 2012. Finnish A'-movement: Edges and Islands (Studies in Cognitive Science 2). Helsinki: University of Helsinki.

Jokilehto, Dara. 2017. Topics: Structure and function. Doctoral dissertation. Université de Genève.

Kaiser, Elsi. 2002. The syntax-pragmatics interface and Finnish ditransitive verbs. In M. van Koppen, E. Thrift, E. J. van der Torre and M. Zimmermann (eds.) Proceedings of the 9th Annual Conference of the Student Organization of Linguistics in Europe (ConSOLE IX), Lund. Leiden: Student Organisation of Linguistics in Europe (SOLE).

Kaiser, Elsi. 2006. Negation and the left periphery in Finnish. Lingua 116. 341-350.

Kaiser, Elsi and John C. Trueswell. 2004. The role of discourse context in the processing of a flexible word-order language. Cognition 94. 113-147.

Karttunen, Lauri and Martin Kay. 1985. Parsing in a free word order language. In D. R. Dowty, L. Karttunen and A. M. Zwicky (eds.) Natural language parsing. Cambridge: Cambridge University Press. 279-306.

Kitahara, Hisatsugu. 2002. Scrambling, case, and interpretability. In S. D. Epstein and D. T. Seely (eds.) Derivation and explanation in the Minimalist Program. Malden, MA \& Oxford: Blackwell. 167-179.

Koskinen, Päivi. 1998. Features and categories: Non-finite constructions in Finnish. Doctoral dissertation. University of Toronto.

Krifka, Manfred. 2007. Negated antonyms: Creating and filling the gap. In U. Sauerland and P. Stateva (eds.) Presupposition and implicature in compositional semantics. New York: Palgrave Macmillan. 163-177.

Lambrecht, Knud. 1994. Information structure and sentence form. A theory of topic, focus, and the mental representations of discourse referents. Cambridge: Cambridge University Press.

Lindén, Eeva. 1959. Hypotaktisen sanajärjestyksen tehtävistä lounaismurteissa [On the role of hypotactic order in south-western dialects]. Virittäjä 63. 252-266.

López, Luis. 2009. A derivational syntax for information structure. Oxford: Oxford University Press.

Manninen, Satu. 2003. Finnish PPs and the Phase Impenetrability Condition. In D. Nelson and S. Manninen (eds.) Generative approaches to Finnic and Saami linguistics. Stanford, CA: CSLI Publications. 295-320.

Mitchell, Erika. 1991. Evidence from Finnish for Pollock's theory of IP. Linguistic Inquiry 22. 373-379.

Molnár, Valéria. 1998. Topic in focus. On the syntax, phonology, semantics and pragmatics of the so-called 'constrastive topic' in Hungarian and German. Acta Linguistica Hungarica 45. 1-77.

Molnár, Valéria. 2006. On different kinds of contrast. In V. Molnár and S. Winkler (eds.) The architecture of focus (Studies in Generative Syntax 82). Berlin \& New York: Mouton de Gruyter. 197-233.

Molnár, Valéria and Marja Järventausta. 2003. Discourse configurationality in Finnish and Hungarian. In J. Hetland and V. Molnár (eds.) Structures of focus and grammatical relations (Linguistische Arbeiten 477). Tübingen: Niemeyer. 231-262. 
Neeleman, Ad, Elena Titov, Hans van de Koot and Reiko Vermeulen. 2009. A syntactic typology of topic, focus and contrast. In J. van Craenenbroeck (ed.) Alternatives to cartography. Berlin \& New York: Mouton de Gruyter. 15-52.

Pesetsky, David. 1987. Wh-in-situ: Movement and unselective binding. In E. Reuland and A. G. B. ter Meulen (eds.) The representation of (in)definiteness. Cambridge, MA: MIT Press. 98-129.

Reinhart, Tanya. 1981. Pragmatics and linguistics. An analysis of sentence topics. Philosophica 27. 53-94.

Rizzi, Luigi. 1990. Relativized minimality. MIT Press: Cambridge, MA.

Rizzi, Luigi. 1997. The fine structure of the left periphery. In L. Haegeman (ed.) Elements of grammar. Dordrecht: Kluwer. 281-337.

Schmidt, Andreas. 2016. Udmurt as an OV language. And Finnish as a VO language. Master's thesis. University of Potsdam.

Sperber, Dan and Deirdre Wilson. 1986. Relevance: Communication and cognition. Cambridge, MA \& Oxford: Blackwell.

Suni, Antti. 2008. Puhesynteesi ja lausepaino [Speech synthesis and sentence stress]. Puhe ja kieli 28. 57-72.

Vainikka, Anne. 1989. Deriving syntactic representations in Finnish. Doctoral dissertation. University of Massachusetts Amherst.

Vainikka, Anne and Yonata Levy. 1999. Empty subjects in Finnish and Hebrew. Natural Language \& Linguistic Theory 17. 613-671.

Välimaa-Blum, Riitta. 1988. Finnish existential clauses: Their syntax, pragmatics and intonation. Doctoral dissertation. Ohio State University.

Välimaa-Blum, Riitta. 1993. A pitch accent analysis of intonation in Finnish. UralAltaische Jahrbucher 12. 82-89.

Vallduví, Enric and Maria Vilkuna. 1998. On Rheme and Kontrast. In P. Culicover and L. McNally (eds.) The limits of syntax. New York: Academic Press. 79-106.

Vallduví, Enrique and Elisabet Engdahl. 1996. The linguistic realization of information packaging. Linguistics 34. 459-519.

Vilkuna, Maria. 1989. Free word order in Finnish: Its syntax and discourse functions. Helsinki: SKS.

Vilkuna, Maria. 1995. Discourse configurationality in Finnish. In É. Kiss (1995, 244-268).

Vilkuna, Maria. 2014. More subordinate? Verb-final order and subordination in Finnish dialects. In L. Visapää, J. Kalliokoski and H. Sorva (eds.) Contexts of subordination: Cognitive, typological and discourse perspectives. Amsterdam \& Philadelphia: John Benjamins. 173--202.

Zubizarreta, Maria-Luisa. 1998. Prosody, focus, and word order. Cambridge, MA: MIT Press. 
